\title{
Examination of Genetic Diversity of Common Bean from the Western Balkans
}

\author{
Marko Maras', Barbara Pipan, and Jelka Šuštar-Vozlič \\ Agricultural Institute of Slovenia, Hacquetova ulica 17, 1000 Ljubljana, Slovenia
}

Vida Todorović

Faculty of Agriculture, University of Banja Luka, Bulevar vojvode Petra Bojovića 1A, 78000 Banja

Luka, Republic of Srpska, Bosnia and Herzegovina

Gordana Đurić

Genetic Resources Institute, University of Banja Luka, Bulevar vojvode Petra Bojovića 1A, 78000

Banja Luka, Republic of Srpska, Bosnia and Herzegovina

\author{
Mirjana Vasić \\ Institute of Field and Vegetable Crops, Maksima Gorkog 30, 21000 Novi Sad, Serbia
}

Suzana Kratovalieva and Afrodita Ibusoska

Institute of Agriculture, Blvd. Aleksandar Makedonski bb, 1000 Skopje, Republic of Macedonia

(FYROM)

Rukie Agić

Faculty of Agricultural Sciences and Food, University of Ss. Cyril and Methodius, Blvd. Aleksandar Makedonski bb, 1000 Skopje, Republic of Macedonia (FYROM)

Zdravko Matotan

Podravka d. d., Koprivnica, Ante Starčevića 32, 48000 Koprivnica, Croatia

Tihomir Čupić

Agricultural Institute Osijek, Južno predgrađe 17, 31103 Osijek, Croatia

Vladimir Meglič

Agricultural Institute of Slovenia, Hacquetova ulica 17, SI-1000 Ljubljana, Slovenia

AdDitional INDEX words. Phaseolus vulgaris, landraces, gene pools, gene flow, SSRs

Abstract. In this study, genetic diversity of 119 accessions of common bean (Phaseolus vulgaris) from five former Yugoslav republics constituting the western Balkans was assessed by 13 microsatellite markers. This set of markers has proven before to efficiently distinguish between bean genotypes and assign them to either the Andean or the Mesoamerican gene pool of origin. In this study, 118 alleles were detected or 9.1 per locus on average. Four groups (i.e., Slovene, Croatian, Bosnian, and Serbian) showed similarly high levels of genetic diversity as estimated by the number of different alleles, number of effective alleles, Shannon's information index, and expected heterozygosity. Mildly narrower genetic diversity was identified within a group of Macedonian accessions; however, this germplasm yielded the highest number of private alleles. All five germplasms share a great portion of genetic diversity as indicated by the analysis of molecular variance (AMOVA). On the basis of the scored number of migrants, we concluded that the most intensive gene flow in the region exists in Bosnia and Herzegovina. Cluster analysis based on collected molecular data classified the accessions into two large clusters that corresponded to two gene pools of origin (i.e., Andean and Mesoamerican). We found that Andean genotypes are more prevalent than Mesoamerican in all studied countries, except Macedonia, where the two gene pools are represented evenly. This could indicate that common bean was introduced into the western Balkans mainly from the Mediterranean Basin. Bayesian cluster analysis revealed that in the area studied an additional variation exists which is related to the Andean gene pool. Different scenarios of the origin of this variation are discussed in the article.

Received for publication 10 Feb. 2015. Accepted for publication 14 Apr. 2015. This work was financially supported by FP7 Project CropSustaIn, grant agreement FP7-REGPOT-CT2012-316205, by grant No. 168/01 from the SEE-ERA.NET.PLUS FP7 Regional Programme and by grant P4-0072 from the Slovenian Research Agency. Accessions in Republic of Srpska, were collected through the National Program for Plant Genetic Resources, with a financial support by Ministry of Science and Technology of the Republic of Srpska. We are thankful to Matej Knapič from Agricultural Institute of Slovenia for preparing a geographic map of the western Balkans with collection sites of the studied common bean accessions.

${ }^{1}$ Corresponding author. E-mail: marko.maras@kis.si.
Common bean $(2 \mathrm{n}=2 \mathrm{x}=22)$ is the most important edible food legume for direct human consumption in Europe and in the world as it represents a valuable source of proteins, vitamins, fiber, and minerals (Broughton et al., 2003).

The Andean region and Mesoamerica are distinguished as the two major centers of origin of this species, according to morphological characters (Singh et al., 1991), seed proteins (Gepts et al., 1986), isozymes (Koenig and Gepts, 1989), DNA markers (Freyre et al., 1996), and sequence data (Schmutz et al., 
2014). After its domestication in the Americas, common bean promptly spread worldwide (Zeven, 1997). Introduction of this species in Europe dates to the early 16th century when Spanish and Portuguese sailors brought bean specimens to their homelands from both centers of domestication (Gepts and Bliss, 1988). During the last five centuries of cultivation, many landraces and cultivars evolved under diverse environments and farmer preferences in Europe (Zeven, 1997). Though many local cultivars were lost in the last 60 years, there are still many farmers who maintain old local landraces, which are well adapted to the pedoclimatic conditions peculiar to their limited geographical areas, and who have been exchanging their seeds with surrounding areas, mainly in local markets.

The pathways of dissemination of the common bean into and across Europe were very complex, with several introductions from America, combined with direct exchanges between European and other Mediterranean countries (Papa et al., 2006). In the past two decades, phaseolin seed protein and other genetic markers have been intensively used to analyze the structure of European common bean populations and distribution of the two gene pools. A prevalence of the Andean " $\mathrm{C}$ " and " $\mathrm{T}$ " phaseolin types (76\%) was first detected by Gepts and Bliss (1988), and was then confirmed by Lioi (1989) in an analysis of a large collection from Italy, Greece, and Cyprus (66\% in total), by Logozzo et al. (2007) for a broad European collection (76\%), and by others for Portuguese and Spanish genotypes (Rodino et al., 2001, 2003). Similar distribution of Andean and Mesoamerican genotypes has also been observed in phaseolin and molecular marker analyses at a regional scale (Angioi et al., 2009; Limongelli et al., 1996; Piergiovanni et al., 2000; Sicard et al., 2005; Suštar-Vozlič et al., 2006). Moreover, several studies have focused on hybridization between the Andean and Mesoamerican gene pools in Europe. This phenomenon was first evidenced in the Iberian Peninsula by analyzing phaseolins, allozymes, and morphological characters (Rodino et al., 2006; Santalla et al., 2002), and later by inter-simple sequence repeat and simple sequence repeat (SSR) markers from both the chloroplast and nuclear genomes of European genotypes (Angioi et al., 2009, 2010; Sicard et al., 2005).

Information on genetic diversity of common bean in the western Balkans that encompasses former Yugoslav republics (i.e., Slovenia, Croatia, Bosnia and Herzegovina, Macedonia, and Serbia) is scarce. In this region, common bean represented a very important food in the human diet for centuries. Until World War II, this crop was grown on large areas ( $>1$ million ha) in the field often together with maize (Zea mays). In the second half of the last century new cultivars of both maize and common bean were introduced into crop production, and the old cropping system was abandoned, which subsequently, lead to a great reduction of the areas covered by beans $(\approx 120,000$ ha).

Different approaches for assessing diversity at the molecular level are presently available. Microsatellites have been considered as the reference markers for cultivar fingerprinting in common bean because they are codominant, widely distributed in the genome, highly polymorphic, and highly repeatable (Powell et al., 1996; Yu et al., 1999).

In this study, the genetic diversity of common bean from the western Balkans was assessed by SSR markers. A total of 13 markers that proved in previous studies (Maras et al., 2006, 2013) to be highly polymorphic and as efficient as amplified fragment length polymorphism markers in distinguishing common bean genotypes according to their gene pool of origin (Maras et al.,
2008) were employed. The collected molecular data allowed us to: 1) examine the relationships among the accessions and the organization of common bean genetic variation in the western Balkans, 2) identify the original gene pool (Andean or Mesoamerican) of the studied plant material, and 3) clarify the bean dissemination process in the western Balkans.

\section{Materials and Methods}

Plant material. A total of 119 common bean landraces from national gene banks of five former Yugoslav republics were used in this study (Table 1; Fig. 1). These included 25 accessions from Bosnia and Herzegovina, 18 from Croatia, 28 from Macedonia [former Yugoslav Republic of Macedonia (FYROM)], 30 from Serbia, and 18 from Slovenia (passport data of the accessions are available upon request).

Out of 18 Slovene accessions included, 14 of them have already been assessed for genetic diversity and phaseolin type in our previous studies (Maras et al., 2013; Šuštar-Vozlič et al., 2006) and were used here as a reference material for the determination of gene pool of origin of the other 105 accessions.

Dna extraction. Total DNA was extracted from bulked leaf material of 10 plants of each accession using BioSprint 15 DNA Plant Kit (Qiagen, Germantown, MD) and MagMax Express Magnetic Particle Processor (Life Technologies, Grand Island, NY) following manufacturer's instructions. Integrity and quality of DNA were evaluated by electrophoresis on $1.0 \%$ agarose gels. Concentrations of DNA samples were determined with a fluorometer (DyNA Quant 200; Hoefer, Holliston, MA).

Molecular analyses. Thirteen SSR loci developed by Metais et al. (2002) and Gaitan-Solis et al. (2002) were employed (Table 2). Amplification reactions were performed with a Veriti Thermal Cycler (Life Technologies) in $10-\mu \mathrm{L}$ reaction mixtures. Each reaction contained $1 \times$ polymerase chain reaction $(\mathrm{PCR})$ buffer, $2 \mu \mathrm{M} \mathrm{MgCl}_{2}, 200 \mu \mathrm{M}$ nucleoside triphosphates, $0.25 \mu \mathrm{M}$ unlabeled right primer, $0.25 \mu \mathrm{M}$ labeled left primer, $0.5 \mathrm{U}$ of Taq DNA Polymerase (Biotools, Madrid, Spain), and $20 \mathrm{ng}$ of genomic DNA. Loci were amplified using a profile of initial denaturation at $95^{\circ} \mathrm{C}$ for $3 \mathrm{~min}$, followed by 30 cycles of strand denaturation at $94^{\circ} \mathrm{C}$ for $30 \mathrm{~s}$, primer annealing at 47 to $62^{\circ} \mathrm{C}$ for $30 \mathrm{~s}$, DNA extension at $72{ }^{\circ} \mathrm{C}$ for $30 \mathrm{~s}$, and final extension at $72^{\circ} \mathrm{C}$ for $4 \mathrm{~min}$. Fluorescently labeled PCR products were mixed with formamide and internal size standard GeneScan350 ROX (Life Technologies) and genotyped on the 3130xl Genetic Analyzer (Life Technologies).

DATA ANALYSES. For each SSR marker, alleles of different sizes were scored. Basic statistics, including observed number of alleles, expected heterozygosity, polymorphic information content (PIC), and probability of identity (PI) were calculated in Identity 1.0 (Wagner and Sefc, 1999) and MicrosatelliteToolkit (Park, 2001). The number of total, effective, and private alleles and alleles with frequency over 5\% were calculated for each of the five groups of accessions using GenAlEx 6.1 (Peakall and Smouse, 2006). The same software was used for the estimation of Shannon's information index and expected heterozygosity of overall loci in single groups of accessions.

Analysis of molecular variance (AMOVA) was performed to statistically assess genetic variation within and among groups of accessions using Arlequin (Excoffier and Lischer, 2010). 
Table 1. List of 119 common bean landraces from national genebanks of five former Yugoslav republics included in this study.

\begin{tabular}{llr}
\hline Place of origin/country & Symbol $^{\mathrm{y}}$ & Accessions investigated \\
\hline Bosnia and Herzegovina & BA & 1-BA, 4-BA, 8-BA, 11-BA, 14-BA, 15-BA, 19-BA, 20-BA, 22-BA, 26A-BA, 30-BA, 31-BA, 32-BA, \\
& & 36-BA, 37-BA, 39-BA, 42-BA, 45-BA, 49-BA, 51-BA, 53-BA, NSKP77-BA, NSKP375-BA, \\
& & NSKB405-BA, NSKP502-BA \\
Croatia & HR & 55-HR, 57-HR, 59-HR, 60-HR, 62-HR, 68-HR, 69-HR, 72-HR, 73-HR, 74-HR, 75-HR, 79-HR, \\
& & 80-HR, 83-HR, 85-HR, NSKP150-HR, NSKP163-HR, NSKB403-HR \\
Macedonia [former & MK & GV1-MK, GV4-MK, GV5-MK, GV7-MK, GV10-MK, GV13-MK, GV19-MK, GV20-MK, \\
Yugoslav Republic of & & GV21-MK, GV22-MK, GV27-MK, GV28-MK, GV31-MK, GV34-MK, GV50-MK, GN1-MK, \\
Macedonia (FYROM)] & & GN2-MK, GN3-MK, GN6-MK, GN9-MK, GN17-MK, GN19-MK, GN22-MK, GN26-MK, \\
& \multirow{3}{*}{ SRB } & NSN28-MK, GN34-MK, GN35-MK, GN41-MK \\
Serbia & & NSKB54_12-RS, NSKB71-RS, NSKB401-RS, NSKB402-RS, NSKP25-RS, NSKP29_12-RS, \\
& & NSKP37-RS, NSKP70-RS, NSKP74-RS, NSKP87-RS, NSKP108-RS, NSKP149-RS, NSKP164-RS, \\
& & NSKP171-RS, NSKP191-RS, NSKP209-RS, NSKP236-RS, NSKP241-RS, NSKP242-RS, \\
& NSKP243-RS, NSKP285-RS, NSKP352-RS, NSKP359-RS, NSKP374-RS, NSKP400-RS \\
Sloveniaz & PHA7-SI (MA), PHA15-SI (A), PHA29-SI (A), PHA59-SI (MA), PHA63-SI, PHA64-SI, PHA65-SI (A), \\
& & PHA66-SI, PHA67-SI, PHA153-SI (A), PHA309-SI (A), PHA316-SI (MA), PHA358-SI (A),
\end{tabular}

${ }^{\mathrm{z}}$ Gene pool of origin of Slovene accessions is reported in parentheses; MA = Mesoamerican gene pool; $\mathrm{A}=\mathrm{Andean}$ gene pool.

${ }^{\mathrm{y}} \mathrm{BA}=$ Bosnia and Herzegovina; $\mathrm{HR}=$ Croatia; $\mathrm{MK}=$ Macedonia; $\mathrm{SI}=$ Slovenia; $\mathrm{SRB}=$ Serbia.

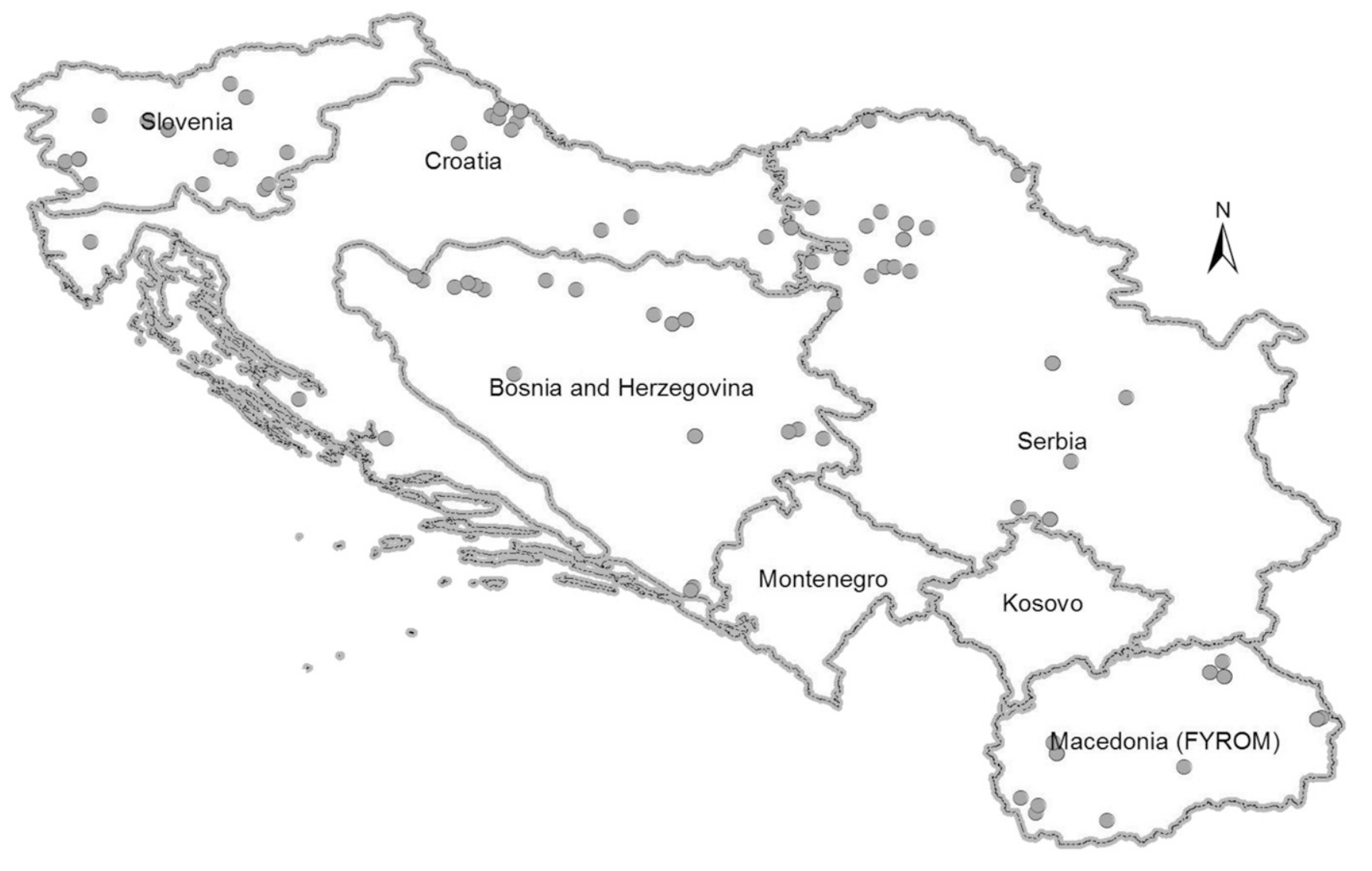

$1: 4.000 .000$

Fig. 1. Geographic map of the western Balkans with collection sites of common bean accessions included in this study. Collection sites are indicated by small grey circles $(\mathrm{FYROM}=$ former Yugoslav Republic of Macedonia).

The unbiased Nei's genetic identity for analyzed accessions performed on the basis of pairwise comparisons between different countries was evaluated using GenAlEx 6.1 (Peakall and Smouse, 2006). The estimation of gene flow among populations was carried out by calculating the effective number of migrants using private allele method of Slatkin (1985) in Genepop 4.1.0 software (Laboratoire de Genetique et Environment, Montpellier, France) reporting the corrected estimated value of Barton and Slatkin (1986).

Populations 1.2.28 software (Langella, 2002) was used in the computation of Nei's standard genetic distance 
(Nei, 1972) from allele frequencies and construction of unweighted pair group method with arithmetic mean (UPGMA) dendrogram in cluster analysis. The UPGMA dendrogram was drawn in TreeView (Page, 1996).

Structure 2.3.3 software (Pritchard et al., 2009) was employed for inferring population structure using a Bayesian approach. Twenty independent runs for each $K$ (from 1 to 12 ) in the case of admixture model were performed and burning period of 10,000 followed by 100,000 Markov chain Monte Carlo repeats were used. The ideal $K$-value was selected based on the increases in likelihood ratios between runs using Evanno's delta $K$ statistic (Evanno et al., 2005) implemented in Structure Harvester (Earl and von Holdt, 2011). An accession was assigned to specific cluster when its percentage of membership was between $0.80 \%$ and $1.00 \%$.

\section{Results}

A total of 118 alleles were scored across the full set of accessions. The average number of alleles per SSR was 9.1, and

Table 2. List of SSR markers assessed in the present study with size and number of alleles $(\mathrm{Na})$ and calculations of expected heterozygosity (He), polymorphic information content (PIC), Shannon's information index (I), and probability of identity (PI).

\begin{tabular}{lrcrrccc}
\hline \multicolumn{7}{c}{ Amplification } \\
Locus & Chr. $^{\mathrm{z}}$ & range & $\mathrm{Na}$ & $\mathrm{He}$ & $\mathrm{PIC}$ & $\mathrm{I}$ & $\mathrm{PI}$ \\
\hline ATA2 $^{\mathrm{y}}$ & 4 & $108-123$ & 5 & 0.66 & 0.60 & 1.77 & 0.175 \\
ATA3 $^{\mathrm{y}}$ & 1 & $121-130$ & 4 & 0.69 & 0.63 & 1.81 & 0.152 \\
ATA4 $^{\mathrm{y}}$ & 1 & $119-143$ & 7 & 0.66 & 0.60 & 1.86 & 0.177 \\
ATA5 $^{\mathrm{y}}$ & 1 & $152-194$ & 10 & 0.70 & 0.66 & 2.21 & 0.129 \\
ATA6 $^{\mathrm{y}}$ & 11 & $119-146$ & 9 & 0.78 & 0.75 & 2.53 & 0.075 \\
ATA7 $^{\mathrm{y}}$ & 2 & $127-160$ & 7 & 0.76 & 0.73 & 2.32 & 0.093 \\
ATA9 $^{y}$ & 9 & $170-200$ & 9 & 0.79 & 0.76 & 2.50 & 0.075 \\
ATA10 $^{\mathrm{y}}$ & 6 & $103-137$ & 8 & 0.76 & 0.72 & 2.26 & 0.098 \\
ATA16 $^{\mathrm{y}}$ & 2 & $139-169$ & 8 & 0.74 & 0.70 & 2.32 & 0.107 \\
GATS91 $^{\mathrm{x}}$ & 2 & $215-275$ & 20 & 0.93 & 0.93 & 4.00 & 0.009 \\
BM170 $^{\mathrm{x}}$ & 6 & $143-179$ & 9 & 0.71 & 0.66 & 2.14 & 0.129 \\
BM183 $^{\mathrm{x}}$ & 7 & $141-193$ & 10 & 0.85 & 0.83 & 2.96 & 0.041 \\
BM210 $^{\mathrm{x}}$ & 7 & $126-186$ & 12 & 0.86 & 0.84 & 3.04 & 0.037 \\
Total & - & - & 118 & - & - & - & $5.9 \times 10^{-15}$ \\
Average & - & - & 9.08 & 0.76 & 0.72 & 2.44 & 0.100 \\
\hline
\end{tabular}

${ }^{\mathrm{z}}$ Location of the microsatellite locus; Chr. $=$ chromosome.

${ }^{y}$ SSR markers developed by Metais et al. (2002).

${ }^{\mathrm{x} S S R}$ markers developed by Gaitan-Solis et al. (2002). ranged from four alleles for ATA3 to 20 alleles for GATS91 (Table 2). The latter also generated the highest values of expected heterozygosity (0.93), PIC (0.93), and Shannon's information index (4.00). The high capacity of GATS91 for distinguishing genotypes was further evidenced by a very low value of PI (0.009). The second most efficient locus in respect to the measured parameters was BM210, followed by BM183 and BM170 (Table 2).

Regarding the genetic diversity residing within the five studied groups, comparable values of expected heterozygosity and average number of different alleles, number of effective alleles, number of alleles with a frequency higher than $5 \%$, and Shannon' information index were observed for accessions from Bosnia and Herzegovina, Croatia, Serbia, and Slovenia (Fig. 2). Notably, lower values of all these parameters were scored for a group of Macedonian accessions. In contrast, the highest number of private alleles (nine) was detected in the Macedonian group, whereas the four other countries yielded 12 private alleles.

The AMOVA revealed that molecular diversity was significantly different $(P<0.01)$ among the five groups (Table 3$)$. It was shown that most of the molecular variation in the studied groups exists among accessions within groups (95\%), with a small portion belonging to the between-group variance component $(5 \%)$.

Table 4 presents the genetic similarity between groups of accessions as estimated by unbiased Nei's genetic identity. The highest value of this parameter was observed for a pair of Bosnian and Croatian accessions (0.984) and the lowest for a pair of geographically distant Macedonian and Slovene accessions $(0.718)$. In general, the parameter was very high $(>0.800)$ when considering all pairwise comparisons with Bosnian, Croatian, Serbian, and Slovene accessions, and significantly lower $(<0.800)$ for all pairwise comparisons that included accessions from Macedonia.

These results were in strong congruence with the observations provided by the calculation of Shannon's mutual information index for all pairwise combinations of countries (Table 5). As estimated by a number of migrants, we can conclude that the most intensive gene flow takes place between Bosnia and neighboring Croatia. The lowest value of this parameter was scored for a pair of Macedonian and Slovene accessions. With regards to the total amount of migrants observed, Bosnia outscored Serbia and Slovenia by 2 -fold and Macedonia by more than 8 -fold.

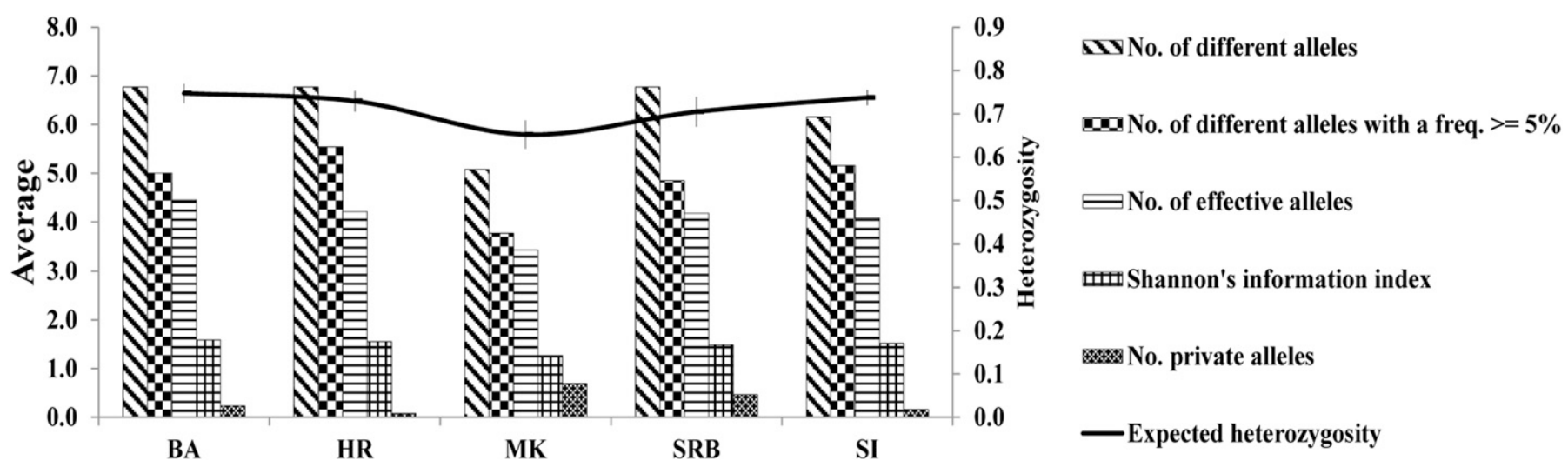

Fig. 2. Allelic patterns observed in five germplasms comprising 119 common bean accessions from five countries: Bosnia and Herzegovina (BA), Croatia (HR), Macedonia (MK), Serbia (SRB), and Slovenia (SI). 
Table 3. Results for the analysis of molecular variance (AMOVA) for common bean accessions from five countries.

\begin{tabular}{lcc}
\hline Source & $\begin{array}{c}\text { Variance } \\
\text { component }\end{array}$ & $\begin{array}{c}\text { Variation } \\
\text { accounted } \\
\text { for }(\%)\end{array}$ \\
\hline $\begin{array}{l}\text { Between geographical } \\
\text { groups }\end{array}$ & 0.237 & $4.69^{* *}$ \\
$\begin{array}{l}\text { Within geographical } \\
\text { groups }\end{array}$ & 4.820 & 95.31 \\
Total & 5.057 & 100.00 \\
\hline$* *$ Significant at $P<0.01$ & &
\end{tabular}

**Significant at $P<0.01$.

Table 4. Unbiased Nei's genetic identity values for pairwise comparisons between five germplasms of common bean accessions from five different countries.

\begin{tabular}{lccccc}
\hline Origin $^{z}$ & BA & HR & MK & SRB & SI \\
\hline BA & - & 0.984 & 0.751 & 0.973 & 0.915 \\
HR & 0.984 & - & 0.724 & 0.944 & 0.858 \\
MK & 0.751 & 0.724 & - & 0.775 & 0.718 \\
SRB & 0.973 & 0.944 & 0.775 & - & 0.813 \\
SI & 0.915 & 0.858 & 0.718 & 0.813 & - \\
Avg & 0.906 & 0.878 & 0.742 & 0.876 & 0.826 \\
\hline
\end{tabular}

$\overline{{ }^{\mathrm{z}} \mathrm{BA}}=$ Bosnia and Herzegovina; HR = Croatia; MK = Macedonia; $\mathrm{SI}=$ Slovenia; $\mathrm{SRB}=$ Serbia .

Table 5. Number of migrants calculated via Shannon's mutual information index for all pairwise countries-combinations.

\begin{tabular}{lccccc}
\hline Origin $^{z}$ & BA & HR & MK & SRB & SI \\
\hline BA & - & 4.347 & 0.294 & 2.802 & 1.936 \\
HR & 4.347 & - & 0.320 & 1.927 & 1.083 \\
MK & 0.294 & 0.320 & - & 0.325 & 0.230 \\
SRB & 2.802 & 1.927 & 0.325 & - & 0.786 \\
SI & 1.936 & 1.083 & 0.230 & 0.786 & - \\
Sum & 9.379 & 7.677 & 1.169 & 5.840 & 4.035
\end{tabular}

${ }^{\mathrm{z}} \mathrm{BA}=$ Bosnia and Herzegovina; HR = Croatia; $\mathrm{MK}=$ Macedonia; $\mathrm{SI}=$ Slovenia; $\mathrm{SRB}=$ Serbia.

On the basis of microsatellite data, the relationship among the 119 accessions was assessed by hierarchical cluster analysis (Fig. 3). A very clear separation of accessions into two large groups could be observed in the dendrogram. On the basis of the classification of 14 Slovene accessions that served as reference genotypes (see Table 1), we were able to discern the studied accessions according to their gene pool of origin, i.e., Andean or Mesoamerican, with characteristic " $\mathrm{C}$," "T," and " $\mathrm{S}$ " phaseolin types (Fig. 3).

The Andean cluster was the largest and contained 72 accessions (61\% of total) from all five countries: 15 from Bosnia and Herzegovina, 12 from Croatia, 14 from Macedonia, 19 from Serbia, and 12 from Slovenia, including all 10 Andean reference accessions.

All countries had their representatives also in the Mesoamerican cluster, which composed of 47 accessions (39\%): 10 from Bosnia and Herzegovina, 6 from Croatia, 14 from Macedonia, 11 from Serbia, and 6 from Slovenia, including 4 Mesoamerican reference accessions.

A strong prevalence of accessions of Andean origin over Mesoamerican was observed in the following four countries: Bosnia and Herzegovina (60\%), Croatia (67\%), Serbia (63\%), and Slovenia (67\%). On the other hand, a notably higher ratio of Mesoamerican genotypes was observed in the Macedonian germplasm $(50 \%)$.

Within the larger Andean cluster, a smaller group of 15 accessions (21\% of Andean and $13 \%$ of total) was distinguished and included 2 Bosnian, 2 Croatian, 4 Macedonian, and 7 Slovene accessions (Fig. 3). Six of these seven Slovene accessions classified in previous studies in a separate Andean subcluster and five of them showed Andean " $C$ " phaseolin type (Maras et al., 2006; Šuštar-Vozlič et al., 2006), which suggests that the set of 15 accessions represents additional variation within the Andean gene pool.

Bayesian clustering was employed in Structure software to identify genetic populations, assign accessions to these populations, and identify admixed accessions (Fig. 4). Delta $K$, an ad hoc statistic that has been recommended to help identify the bestfitting number of populations within a sample (Evanno et al., 2005), was highest at $K=3$. Beside the presence of Andean and Mesoamerican genotypes in all countries, Structure analysis confirmed the existence of an additional third cluster, which was also identified in the UPGMA dendrogram (Andean sub-cluster). The 14 representatives of this cluster with percentage of membership higher than 0.80, were found most abundant in Slovene germplasm (PHA15-SI, PHA29-SI, PHA64-SI, PHA65SI, PHA153-SI, PHA639-SI, PHA642-SI), followed by representatives from Bosnia (1-BA, 32-BA, 37-BA), Serbia (NSKB2_10-RS, NSKB5_10-RS), Macedonia (GV31-MK), and Croatia (57-HR). Four accessions, NSKB403-HR, GV1MK, GV13-MK, and GN22-MK, that grouped together within the Andean sub-cluster in UPGMA dendrogram were shown in Structure analysis to score percentage of membership lower than 0.80 and thus were not assigned to the same cluster. There were 10 more accessions (14 in total) with admixed genetic structure that showed percentage of membership to any of the three clusters lower than 0.80 .

It should also be noted that at $K=2$, all 14 accessions from the additional cluster showed predominantly Andean origin with percentage of membership higher than 0.68 , while out of 14 accessions with admixed genetic structure at $K=3$ only two were classified within Mesoamerican and one within Andean gene pool at $K=2$ with a percentage of membership higher than 0.80 (Fig. 4).

\section{Discussion}

Thirteen SSR markers, demonstrated previously for their efficiency to distinguish among common bean genotypes and assign them according to their gene pool of origin (Maras et al., 2006, 2013), have been employed in this study to assess genetic diversity of 119 common bean accessions from the five former Yugoslav republics that constitute the western Balkans. This study is complementary to the previous genetic diversity assessments of Slovene and Austrian germplasm (Maras et al., 2006, 2013; Šuštar-Vozlič et al., 2006), the two countries that represent a geographic bridge between the western Balkans and central Europe.

Marker diversity in terms of average number of SSR alleles per marker (9.1) for the combination of 13 markers and 119 accessions in this study was comparable to the previous study (Maras et al., 2013), where 10.5 alleles were detected on average in 167 bean accessions genotyped by 14 SSR markers. This is notably higher in comparison with the values reported in 


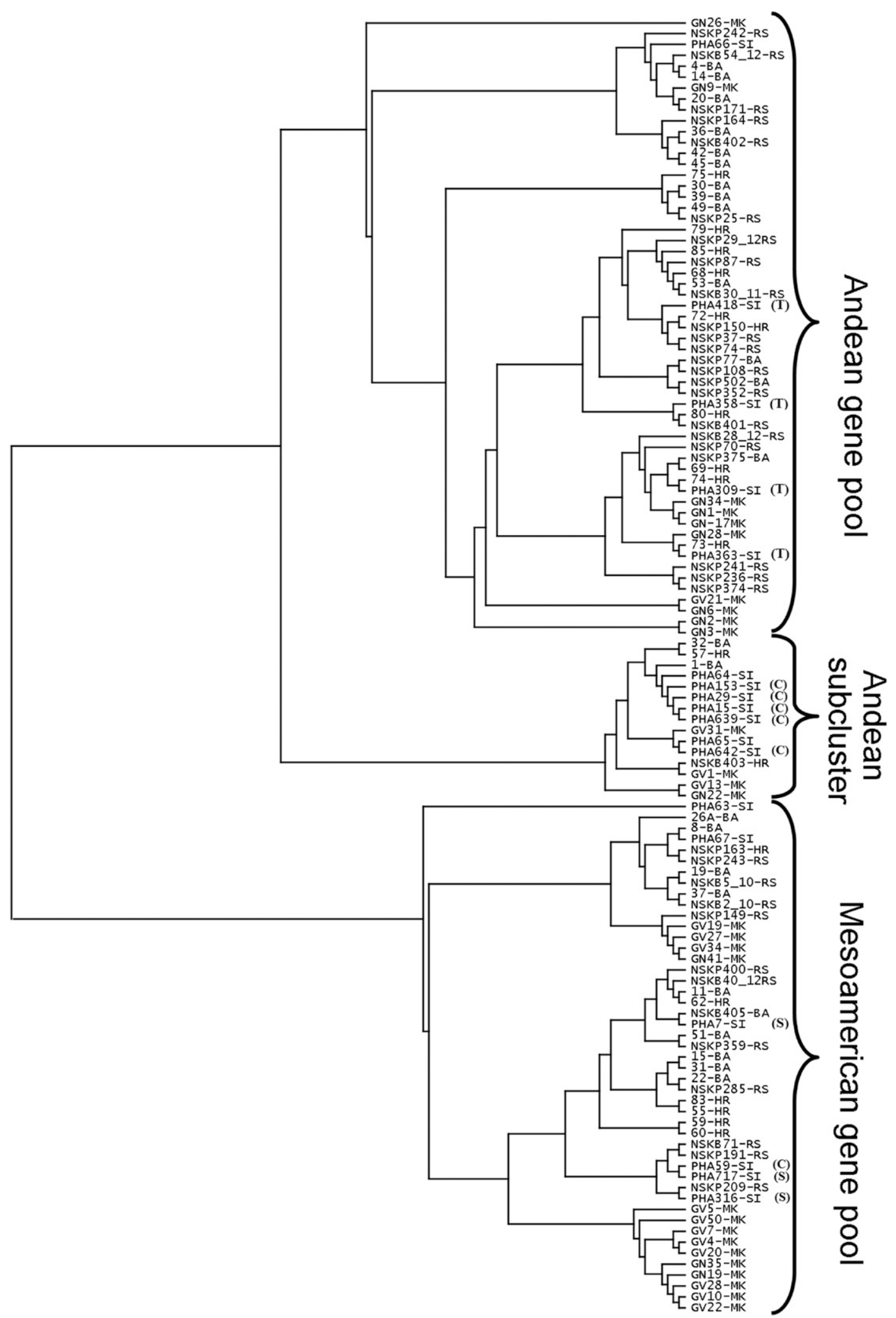

Fig. 3. UPGMA dendrogram revealing genetic relationship among 119 common bean accessions from five countries based on Nei's genetic distance.

the studies of common bean genetic diversity carried out by Blair et al. (2006) and Zhang et al. (2008), similar to values scored by Asfaw et al. (2009) and Blair et al. (2012) but lower than values found by Kwak and Gepts (2009).
As indicated by other parameters of marker diversity, i.e., Shannon's information index, expected He, PIC, and PI; the SSRs proved to be a very powerful tool in resolving genetic relatedness between common bean genotypes. This is in strong 

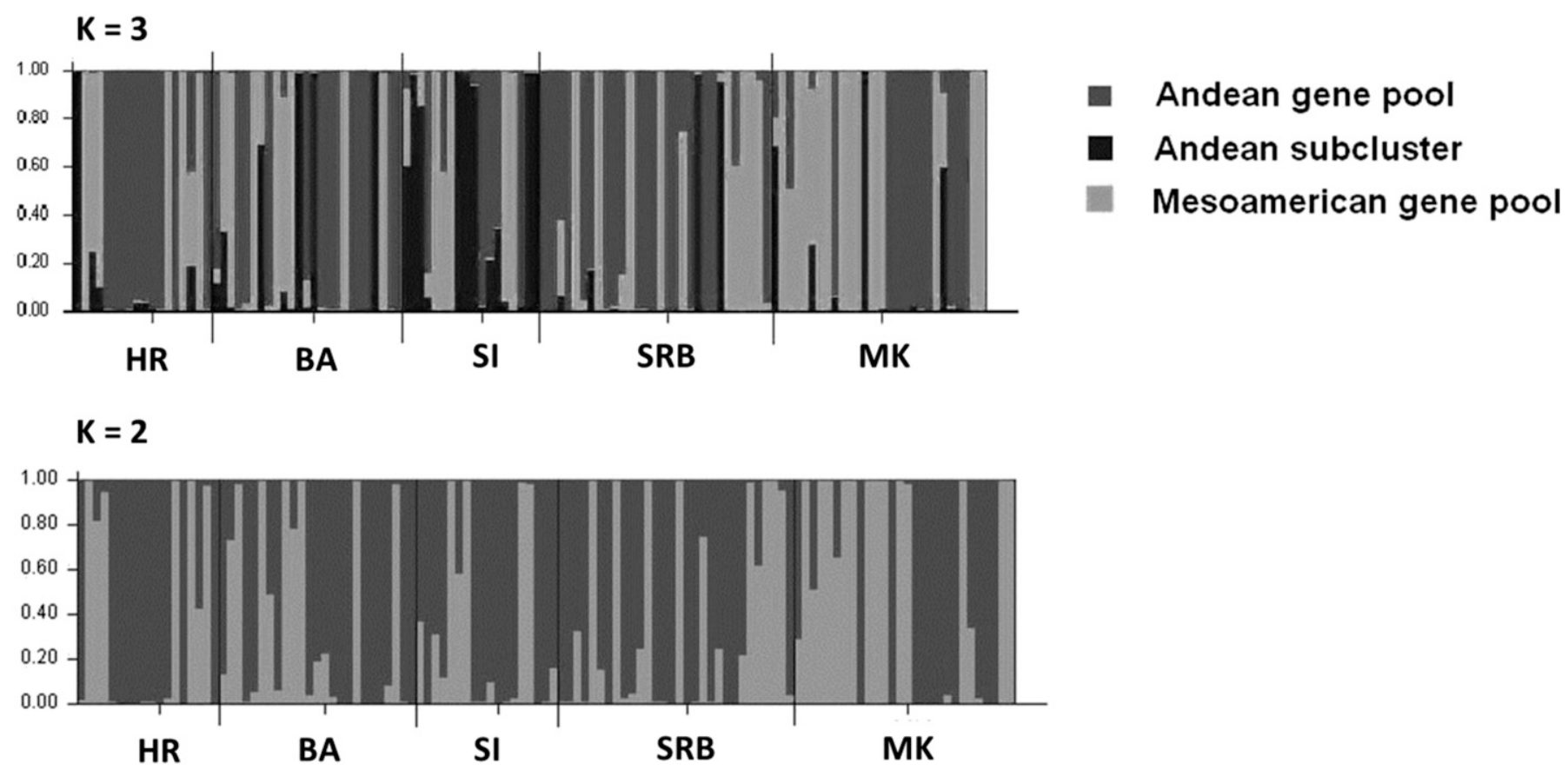

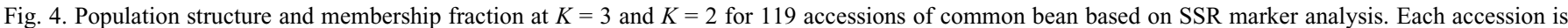
represented by a vertical histogram with three colors segments that represent the accession's membership fraction in three clusters (dark gray = Andean gene pool; black $=$ Andean sub-cluster; pale gray $=$ Mesoamerican gene pool $) ; \mathrm{HR}=$ Croatia; $\mathrm{BA}=\mathrm{Bosnia}$ and Herzegovina; $\mathrm{SI}=\mathrm{Slovenia} ; \mathrm{SRB}=\mathrm{Serbia} ; \mathrm{MK}=\mathrm{Macedonia}$.

congruence with the observation of Kwak and Gepts (2009) and Blair et al. (2009).

Considering the five groups of accessions, we found that four groups (BA, HR, SRB, and SI) possess comparable marker diversity as indicated by the scored parameters, e.g., number of different alleles, number of effective alleles, Shannon's information index, while the Macedonian group, on the other hand, contained fewer alleles. However, this group included the highest number of private alleles.

Though AMOVA showed that all five studied germplasms share a great portion of genetic variation, a notable distinctness of Macedonian group of accessions was observed and evaluated via different diversity parameters. Beside the abundance of private alleles, the distinctness of Macedonian germplasm was further revealed through calculation of unbiased Nei's genetic identity. The lowest values of this parameter for all possible pairwise comparisons were scored for the pairs that included Macedonian group of accessions suggesting that the introgression of bean genotypes from surrounding countries, i.e., Bulgaria and Greece, where distinguishable patterns of common bean genetic diversity were found with a prevalence of Mesoamerican genotypes (Lioi, 1989; Svetleva et al., 2006), must have played an important role in the formation of genetic structure of Macedonian germplasm. On the other hand, the highest value of the unbiased Nei's genetic identity was measured for Bosnia and Herzegovina, indicating that the most intensive exchange of genetic material within the western Balkans takes place in this region. This is not surprising because Bosnia and Herzegovina lie in the heart of the western Balkans and connects the trading routes from Slovenia on the west, Croatia on the north, and Serbia on the east. This observation was further supported by the highest number of migrants calculated via Shannon's mutual information index for Bosnian germplasm.
In the cluster analysis based on microsatellite data, all single accessions were successfully distinguished. In the present study, two large groups were observed corresponding to two common bean gene pools with characteristic phaseolin types. The same clustering pattern of common bean assessed by molecular markers has been reported for Slovenia (Maras et al., 2013; Šuštar-Vozlič et al., 2006), Italy (Limongelli et al., 1996; Piergiovanni et al., 2000; Sicard et al., 2005), Spain (Rodino et al., 2003), Bulgaria (Svetleva et al., 2006), Brazil (Burle et al., 2010), Ethiopia and Kenya (Asfaw et al., 2009), and China (Zhang et al., 2008). Both groups from the UPGMA dendrogram contained accessions from all five countries implying that genotypes from both major centers of common bean genetic diversity have been cultivated in the area of former Yugoslavia. Although there was no evidence of grouping of accessions with regards to the country of origin, obvious tendency in the distribution of the two gene pools across the territory was observed in this study. Very high frequency $(50 \%)$ of Mesoamerican genotypes was found in Macedonia, which is located on the southern boundaries of the former Yugoslavia, and much lower in the central and, especially, northern parts of the area studied. The very high proportion of Andean genotypes in the northern part is in agreement with the observation of Maras et al. (2013) who found that the prevalence of Andean genotypes in Slovenia is as strong as in Italy. As indicated in this study, it seems that the influence of the strong gene flow from the west spreads deeply in the territory of former Yugoslavia.

As shown by Angioi et al. $(2010,2011)$ and Logozzo et al. (2007), 67\% of European germplasm is of Andean origin. The authors identified three macro areas where Andean genotypes were particularly abundant. These include the Iberian Peninsula, Italy, and central-northern Europe. However, in eastern and southeastern Europe, the proportion of the Mesoamerican 
type increases. These observations are further supported by earlier findings from Spain (Pérez-Vega et al., 2009; Rodino et al., 2003), Portugal (Rodino et al., 2001, 2003), Italy (Angioi et al., 2009; Lioi, 1989; Piergiovanni et al., 2000) where Andean genotypes were prevalent, and Greece (Lioi, 1989) and Bulgaria (Svetleva et al., 2006) where high frequencies (around 50\%) of Mesoamerican genotypes were observed. On the basis of the results presented, we can classify Slovenia, Croatia, Serbia, and Bosnia and Herzegovina among the Mediterranean countries with prevalent Andean genotypes, while Macedonia resembles more to the countries on the east with predominantly Mesoamerican genotypes.

With respect to the two original genetic diversity centers of common bean, we identified additional distinctive variation in UPGMA dendrogram and Structure analysis. Both statistical approaches along with the specific " $C$ " phaseolin pattern indicated that this variation is based within the Andean gene pool and might consist of putative hybrids between the gene pools that were detected extensively across Europe (Angioi et al., 2010, 2011). Alternatively, it might represent unique variation peculiar to the region under investigation or might have been introduced from other European countries or American continent.

As shown by Angioi et al. (2010) and Gioia et al. (2013), who assessed more than 250 European common bean accessions for SSRs, phaseolin, and Pv-shatterproof1, about one third of the European $P$. vulgaris might represent hybrids between the two gene pools. In our study, the frequency of putative hybrids in the western Balkans was relatively low and resembled more to germplasm from America and Africa, where ratios between $1 \%$ and $12 \%$ were reported (Asfaw et al., 2009; Blair et al., 2010; Gioia et al., 2013). This implies that despite $P$. vulgaris being an autogamous species, hybridization in the area studied might not be uncommon. Putative hybrids are of great value since introgressions between the gene pools might have created new interesting combinations of traits, such as a higher adaptability to environmental stresses, diseases or insects, and might have helped to break the negative associations between seed weight and yield potential (Gioia et al., 2013; Johnson and Gepts, 1999).

Alternatively, a set of distinctive genotypes in regard to the two major gene pools could represent unique variation that has evolved in the area studied or has been introduced from the abroad. Recently, Raggi et al. (2013) reported the existence of genotypes from the Italian Peninsula with unique genetic structure that is distinguishable from other Andean genotypes according to ecogeographical features determined by altitude, and suggested that the observed genetic diversity pattern could be the result of different selective forces associated with specific environmental conditions and several hundred years of continuous cultivation.

\section{Literature Cited}

Angioi, S.A., D. Rau, G. Attene, L. Nanni, E. Bellucci, G. Logozzo, V. Negri, P.L. Spagnoletti Zeuli, and R. Papa. 2010. Beans in Europe: Origin and structure of the European landraces of Phaseolus vulgaris L. Theor. Appl. Genet. 121:829-843.

Angioi, S.A., D. Rau, L. Nanni, E. Bellucci, R. Papa, and G. Attene. 2011. The genetic make-up of the European landraces of the common bean. Plant Genet. Resources 9:197-201.

Angioi, S.A., D. Rau, M. Rodriguez, G. Logozzo, F. Desiderio, R. Papa, and G. Attene. 2009. Nuclear and chloroplast microsatellite diversity in Phaseolus vulgaris L. from Sardinia (Italy). Mol. Breed. 23:413-429.

Asfaw, A., M. Blair, and C. Almekinders. 2009. Genetic diversity and population structure of common bean (Phaseolus vulgaris L.) landraces from the east African highlands. Theor. Appl. Genet. 120:1-12.

Barton, N.H. and M. Slatkin. 1986. A quasi-equilibrium theory of the distribution of rare alleles in a subdivided population. Heredity 56:409-416.

Blair, M.W., L.M. Díaz, H.F. Buendia, and M.C. Duque. 2009. Genetic diversity, seed size associations and population structure of a core collection of common beans (Phaseolus vulgaris L.). Theor. Appl. Genet. 119:955-973.

Blair, M.W., M.C. Giraldo, H.F. Buendia, E. Tovar, M.C. Duque, and S.E. Beebe. 2006. Microsatellite marker diversity in common bean (Phaseolus vulgaris L.). Theor. Appl. Genet. 113:100-109.

Blair, M.W., L.F. González, M. Kimani, and L. Butare. 2010. Genetic diversity, inter-gene pool introgression and nutritional quality of common beans (Phaseolus vulgaris L.) from central Africa. Theor. Appl. Genet. 121:237-248.

Blair, M.W., A. Soler, and A.J. Cortés. 2012. Diversification and population structure in common beans (Phaseolus vulgaris L.). PLoS ONE 7(11):e49488.

Broughton, W.J., G. Hernandez, M. Blair, S. Beebe, P. Gepts, and J. Vanderleyden. 2003. Beans (Phaseolus spp.) - Model food legumes. Plant Soil 252:55-128.

Burle, M.L., J.R. Fonseca, J.A. Kami, and P. Gepts. 2010. Microsatellite diversity and genetic structure among common bean (Phaseolus vulgaris L.) landraces in Brazil, a secondary center of diversity. Theor. Appl. Genet. 121:801-813.

Earl, D.A. and B.M. von Holdt. 2011. STRUCTURE HARVESTER: A website and program for visualizing STRUCTURE output and implementing the Evanno method. Conservation Genet. Resources 3:429-431.

Evanno, G., S. Regnaut, and J. Goudet. 2005. Detecting the number of clusters of individuals using the software SRUCTURE: A simulation study. Mol. Ecol. 14:2611-2620.

Excoffier, L. and H. Lischer. 2010. Arlequin suite ver 3.5: A new series of programs to perform population genetics analyses under Linux and Windows. Mol. Ecol. Resources 10:564-567.

Freyre, R., R. Rios, L. Guzman, D.G. Debouck, and P. Gepts. 1996. Ecogeographic distribution of Phaseolus spp. (Fabaceae) in Bolivia. Econ. Bot. 50:195-215.

Gaitan-Solis, E., M.C. Duque, K.J. Edwards, and J. Tohme. 2002. Microsatellite repeats in common bean (Phaseolus vulgaris): Isolation, characterization, and cross-species amplification in Phaseolus ssp. Crop Sci. 42:2128-2136.

Gepts, P. and F.A. Bliss. 1988. Dissemination paths of common bean (Phaseolus vulgaris, Fabaceae) deduced from phaseolin electrophoretic variability. II. Europe and Africa. Econ. Bot. 42:86-104.

Gepts, P., T.C. Osborn, K. Rashka, and F.A. Bliss. 1986. Phaseolinprotein variability in wild forms and landraces of the common bean (Phaseolus vulgaris) - Evidence for multiple centers of domestication. Econ. Bot. 40:451-468.

Gioia, T., G. Logozzo, G. Attene, E. Bellucci, S. Benedettelli, V. Negri, R. Papa, and P. Spagnoletti Zeuli. 2013. Evidence for introduction bottleneck and extensive inter-gene pool (Mesoamerica $\times$ Andes) hybridization in the European common bean (Phaseolus vulgaris L.) germplasm. PLoS ONE 8(10):e75974.

Johnson, W.C. and P. Gepts. 1999. Segregation for performance in recombinant inbred populations resulting from inter-gene pool crosses of common bean (Phaseolus vulgaris L.). Euphytica 106:5-56.

Koenig, R. and P. Gepts. 1989. Allozyme diversity in wild Phaseolus vulgaris: Further evidence for two major centers of genetic diversity. Theor. Appl. Genet. 78:809-817.

Kwak, M. and P. Gepts. 2009. Structure of genetic diversity in the two major gene pools of common bean (Phaseolus vulgaris L., Fabaceae). Theor. Appl. Genet. 118:979-992. 
Langella, O. 2002. Population 1.2.28. Logiciel de génétique des populations. Laboratoire populations, génétique et évolution, Gif-surYvette, France.

Limongelli, G., G. Laghetti, P. Perrino, and A.R. Piergiovanni. 1996. Variation of seed storage proteins in landraces of common bean (Phaseolus vulgaris L.) from Basilicata, southern Italy. Euphytica 92:393-399.

Lioi, L. 1989. Variation of the storage protein phaseolin in common bean (Phaseolus vulgaris L.) from the Mediterranean area. Euphytica 44:151-155.

Logozzo, G., R. Donnoli, L. Macaluso, R. Papa, H. Knupffer, and P.L. Spagnoletti Zeuli. 2007. Analysis of the contribution of Mesoamerican and Andean gene pools to European common bean (Phaseolus vulgaris L.) germplasm and strategies to establish a core collection. Genet. Resources Crop Evol. 54:1763-1779.

Maras, M., S. Sušnik, J. Suštar-Vozlič, and V. Meglič. 2006. Temporal changes in genetic diversity of common bean (Phaseolus vulgaris L.) accessions cultivated between 1800 and 2000. Russ. J. Genet. 42:775-782.

Maras, M., J. Šuštar-Vozlič, B. Javornik, and V. Meglič. 2008. The efficiency of AFLP and SSR markers in genetic diversity estimation and gene pool classification of common bean (Phaseolus vulgaris L.). Acta Agr. Slov. 91:87-96.

Maras, M., J. Šuštar-Vozlič, W. Kainz, and V. Meglič. 2013. Genetic diversity and dissemination pathways of common bean in central Europe. J. Amer. Soc. Hort. Sci. 138:297-305.

Metais, I., B. Hamon, R. Jalouzot, and D. Peltier. 2002. Structure and level of genetic diversity in various bean types evidenced with microsatellite markers isolated from a genomic enriched library. Theor. Appl. Genet. 104:1346-1352.

Nei, M. 1972. Genetic distance between populations. Amer. Nat. 106:283-292.

Page, R.D.M. 1996. TREEVIEW: An application to display phylogenetic trees on personal computers. Comput. Appl. Biosci. 12:357-358.

Papa, R., L. Nanni, D. Sicard, D. Rau, and G. Attene. 2006. Evolution of genetic diversity in Phaseolus vulgaris L., p. 121-142. In: T.J. Motley, N. Zerega, and H. Cross (eds.). Darwin's harvest: New approaches to the origins, evolution and conservation of crops. Columbia University Press, New York, NY.

Park, S.D.E. 2001. The Excel microsatellite-toolkit. Animal Genomics Lab., Univ. College Dublin, Dublin, Ireland.

Peakall, R. and P.E. Smouse. 2006. GENALEX 6: Genetic analysis in Excel. Population genetic software for teaching and research. Mol. Ecol. Notes 6:288-295.

Pérez-Vega, E., A. Campa, L. De la Rosa, R. Giraldez, and J.J. Ferreira. 2009. Genetic diversity in a core collection established from the main bean genebank in Spain. Crop Sci. 49:1377-1386.

Piergiovanni, A.R., G. Taranto, and D. Pignone. 2000. Diversity among common bean populations from the Abruzzo region (central Italy): A preliminary inquiry. Genet. Resources Crop Evol. 47:467-470.

Powell, W., G.C. Machray, and J. Provan. 1996. Polymorphism revealed by simple sequence repeats. Trends Plant Sci. 1:215-222.
Pritchard, J.K., X. Wen, and D. Falush. 2009. STRUCTURE ver. 2.3. Univ. Chicago, Chicago, IL.

Raggi, L., B. Tiranti, and V. Negri. 2013. Italian common bean landraces: Diversity and population structure. Genet. Resources Crop Evol. 60:1515-1530.

Rodino, P., M. Santalla, A.M. De Ron, and S.P. Singh. 2003. A core collection of common bean from the Iberian Peninsula. Euphytica 131:165-175.

Rodino, P., M. Santalla, A.M. González, A.M. De Ron, and S.P. Singh. 2006. Novel genetic variation in common bean from the Iberian Peninsula. Crop Sci. 46:2540-2546.

Rodino, P., M. Santalla, I. Montero, P.A. Casquero, and A.M. De Ron. 2001. Diversity of common bean (Phaseolus vulgaris L.) germplasm from Portugal. Genet. Resources Crop Evol. 48:409-417.

Santalla, M., P. Rodino, and A.M. De Ron. 2002. Allozyme evidence supporting southwestern Europe as a secondary center of genetic diversity for the common bean. Theor. Appl. Genet. 104:934-944.

Schmutz, J., P.E. McClean, S. Mamidi, G.A. Wu, S.B. Cannon, J. Grimwood, J. Jenkins, S. Shu, Q. Song, C. Chavarro, M. TorresTorres, V. Geffroy, S.M. Moghaddam, D. Gao, B. Abernathy, K. Barry, M. Blair, M.A. Brick, M. Chovatia, P. Gepts, D.M. Goodstein, M. Gonzales, U. Hellsten, D.L. Hyten, G. Jia, J.D. Kelly, D. Kudrna, R. Lee, M.M.S. Richard, P.N. Miklas, J.M. Osorno, J. Rodrigues, V. Thareau, C.A. Urrea, M. Wang, Y. Yu, M. Zhang, R.A. Wing, P.B. Cregan, D.S. Rokhsar, and S.A. Jackson. 2014. A reference genome for common bean and genome-wide analysis of dual domestications. Nat. Genet. 46:707-713.

Sicard, D., L. Nanni, O. Porfiri, D. Bulfon, and R. Papa. 2005. Genetic diversity of Phaseolus vulgaris L. and P. coccineus L. landraces in central Italy. Plant Breed. 124:464-472.

Singh, S.P., P. Gepts, and D.G. Debouck. 1991. Races of common bean (Phaseolus vulgaris, Fabaceae). Econ. Bot. 45:379-396.

Slatkin, M. 1985. Rare alleles as indicators of gene flow. Evolution 39:53-65.

Svetleva, D., G. Pereira, J. Carlier, L. Cabrita, J. Leitao, and D. Genchev. 2006. Molecular characterization of Phaseolus vulgaris L. genotypes included in Bulgarian collection by ISSR and AFLP analyses. Sci. Hort. 109:198-206.

Šuštar-Vozlič, J., M. Maras, B. Javornik, and V. Meglič. 2006. Genetic diversity and origin of Slovene common bean (Phaseolus vulgaris L.) germplasm as revealed by AFLP markers and phaseolin analysis. J. Amer. Soc. Hort. Sci. 131:242-249.

Wagner, H.W. and K.M. Sefc. 1999. Identity 1.0. Freeware program for the analysis of microsatellite data. Ctr. Appl. Genet., Univ. Agr. Sci., Vienna, Austria.

Yu, K.F., S.J. Park, and V. Poysa. 1999. Abundance and variation of microsatellite DNA sequences in beans (Phaseolus and Vigna). Genome 42:27-34.

Zeven, A.C. 1997. The introduction of the common bean (Phaseolus vulgaris L.) into western Europe and the phenotypic variation of dry beans collected in the Netherlands in 1946. Euphytica 94:319-328.

Zhang, X.Y., M.W. Blair, and S.M. Wang. 2008. Genetic diversity of Chinese common bean (Phaseolus vulgaris L.) landraces assessed with simple sequence repeat markers. Theor. Appl. Genet. 117:629-640. 